https://www.journal-imab-bg.org

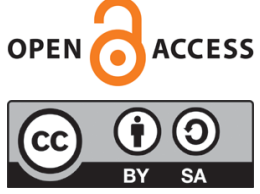

Original article

\title{
PREVALENCE OF MTHFR GENE 677C>T POLY- MORPHISM IN THE PATIENTS WITH PSORIASIS VULGARIS
}

\author{
Borislav Dimitrov ${ }^{1}$, Dimitar Gospodinov ${ }^{2}$,Veronika Gincheva ${ }^{2}$, Regina Komsa- \\ Penkova $^{1}$ \\ 1) Department of Chemistry and Biochemistry, Faculty of Pharmacy, Univer- \\ sity of Medicine, Pleven, Bulgaria \\ 2) Department of Dermatology, Venereology and Allergology, Medical Univer- \\ sity - Pleven, Bulgaria.
}

\section{ABSTRACT:}

The study aimed to investigate the relationship between carriage of $677 \mathrm{C}>\mathrm{T}$ polymorphism in the gene of methylene tetrahydrofolate reductase (MTHFR)and plaque psoriasis in patients in Bulgaria.

We examined the prevalence of MTHFR C677T genotype in patients with psoriasis, as well as the relationship of the polymorphism with disease severity. Our study covered63 patients with psoriasis and 98psoriasis-free control subjects from northern Bulgaria. MTHFR677C $>$ T genotype was verified by the PCR-RFLP method. There was no significant difference between carriage of TT genotype among the patients and controls: $12.7 \%$ versus $10.8 \%$ in controls, OR 1.203, (CI 95\% 0465-3.175), p >0.05 respectively. There was a higher PASI score in patients, carriers of TT genotype of MTHFR polymorphism $677 \mathrm{C}>\mathrm{T}$ than in non-carriers, 28.18 versus 24.87 respectively, but not significant.

Conclusion: Carriage of TT genotype of MTHFR polymorphism $677 \mathrm{C}>\mathrm{T}$ was not associated with Psoriasis Vulgaris in the northern Bulgarian population when compared to healthy controls.

Keywords: Psoriasis, MTHFR polymorphism 677C $>$ T, PASI, Bulgarian population,

\section{INTRODUCTION}

Psoriasis (plaque psoriasis) is a chronic dermatological autoimmune disease with a heavy inflammation component, many comorbidities, and still unclear pathogenesis. 2$3 \%$ of the human population is affected. [1] The disease is consideredmultifactorial, involving many systems of the human body [2] and multigenic, with at least 159 genes involved. One of the investigated genes is a gene of MTHFR. The locus of MTHFR is located on the short arm of chromosome 1 (1p36.3).[3]

The enzyme MTHFR is a glycoprotein of molecular weight 70 77000 $\mathrm{kDa}[3]$, its activity depends onthe availability of FAD as a cofactorand $\mathrm{NAD}(\mathrm{P}) \mathrm{H}$ as a source of reducing equivalent.[4] The enzyme redistributes folate types in the direction of DNA synthesisor a homocysteine remethylation to methionine. [5]
The folate derivative 5,10-methylenetetrahydrofolate is metabolized to5-methyltetrahydrofolate for the regeneration of methionine from homocysteine by methionine synthase.[6]Methionine is the main substrate to produce S-adenosyl-Methionine(SAM)- a universal donor of methyl groupsfor DNA and protein methylation.[7] DNA methylation is a crucial epigenetic mechanism for the regulation of DNA activity.[8]

Twenty four mutations/polymorphisms were discovered in the gene of MTHFR that causesa decrease in enzyme activity.[9]One of the most investigated polymorphisms is asubstitution of cytosine for thymine at position 677 of the MTHFR gene, which leads to the formation of the thermolabile form of the enzyme caused by alanine to valinereplacement.[10]In a heterozygous state, the polymorphism causes a $30 \%-40 \%$ reduction of the enzyme activity, whereas in the homozygous state, roughly $60 \%-70 \% .[11]$

In the case of reduced levels of folate, the homozygous MTHFR677C $>\mathrm{T}$ polymorphism is considered harmful.[5] Failtometabolize 5,10-methylenetetrahydrofolate to 5-methyltetrahydrofolatecould causea rise of homocysteine levels in plasma.[10] Various diseases are associated with carriage of polymorphism MTHFR677C $>$ T: vascular diseases, male infertility[12], female infertility, neurological and psychiatric diseases, diabetes, cancers[13], hyperhomocysteinemia which is a risk factor for cardiovascular diseases[14] and psoriasis.[15]

Searches related tothe MTHFR $677 \mathrm{C}>\mathrm{T}$ gene polymorphism frequency show variation between different populationsand regionsof the world from $4 \%$ to $32 \%$. Moreover, the data on mutation carriage in psoriatic patients varies significantly from the conclusion for the Malaysian population that the MTHFR $677 \mathrm{C}>\mathrm{T}$ genepolymorphism and the $\mathrm{T}$ allele occurrence were not significantly associated with psoriasis vulgaris [16] to the controversial finding that the T-allele and T-containing genotypes (TT, CT) of MTHFR C677T are significantlylinked with psoriasis susceptibility while Callele and $\mathrm{CC}$ genotype not. [17]There are no studies on the frequency of this polymorphism in psoriatic patients 
in the Bulgarian population. This fact motivated us to evaluate the role of polymorphism $677 \mathrm{C}>\mathrm{T}$ in the MTHFR gene in patients with plaque psoriasis in northern Bulgaria.

\section{MATERIALS AND METHODS}

\section{Selection and evaluation of Patients}

Our study was conducted at the Clinic of Dermatology\& Venereology, UMBAL - Pleven, Bulgaria, and the University of Medicine-Pleven, Bulgaria.A total of 63 (51 males and 12 females) patients with plaque psoriasis and 98(64 males and 34 female) control subjects without psoriasis were selected for the study.All subjects were Caucasian. Psoriasis was diagnosed on the basis of clinical feature and histological verification. The Psoriasis Area Severity Index (PASI) is an index used to express the severity of psoriasis. It combines the severity (erythema, induration and desquamation) and the percentage of the affected area.

For each patient, the Psoriasis Area and Severity Index (PASI) was calculated to determine the severity of the dermatosisbased on erythema, induration and desquamation of the plaques and the percentage of affected areaof the skin.(skin surface) Values above 10 determine a severe form of the disease.

The anthropometric, clinical, and laboratory data were collected for each patient. Patient information, including demographic features, was collected using a questionnaire.

\section{Laboratory methods}

BMI was calculated according to the formula: body weight $/$ height ${ }^{2} \mathrm{~kg} / \mathrm{cm}^{2}$.

The patients and control subjects without psoriasis were investigated for the carriage of genotype $677 \mathrm{C}>\mathrm{T}$. Blood samples were collected in $6 \mathrm{ml}$ serum test tubes with EDTA.The DNA was extracted by the salting out method. MTHFR genotype $677 \mathrm{C}>\mathrm{T}$ was investigated bythe PCR method Combined withRestriction Fragment Length Polymorphism assay (PCR-RFLP). Hinf ${ }^{2}$ restriction endonuclease was used for restriction analysis.[18]

Fasting Blood Glucose (FBG) and triacylglycerol (TAG) were measured by conventional laboratory methods.

Statistical analysis was realized with Statistical Package for Social Sciences (SPSS) version 23.0. and Microsoft Excel. Statistical significance $\mathrm{p}<0.05$ was used.

Written informed consent was obtained from each participant. The study was approved by the ethics committee of Medical University-Pleven.

\section{RESULTS}

We examined the association between psoriasis and the prevalence of MTHFR C677T genotype in the Bulgarian population, as well as the relationship of the prevalence of the polymorphism and disease severity. The demographic data, clinical parameters and disease severity in the PASI index of the patients are displayedin Table 1.The mean age of the patients was $55.06 \pm 12.310$ years, the age of the diagnosis $38.49 \pm 14.15$ years, the mean BMI was close to the obesity $29.09 \pm 6.023 \mathrm{~kg} / \mathrm{m}^{2}$, the FBG and triglycerides were in the reference range.

Table 1. Characteristics of patients and controls

\begin{tabular}{|l|c|c|}
\hline $\begin{array}{l}\text { DATA } \\
\text { Means } \pm \text { SD }\end{array}$ & Patients & Controls \\
\hline Number of subjects & 63 & 98 \\
\hline Gender Male/Female & $51 / 12$ & $64 / 34$ \\
\hline Mean Age years & $55,06 \pm 12,310$ & $47,53 \pm 12,10)$ \\
\hline $\begin{array}{l}\text { Age of the diagnosis } \\
\text { years }\end{array}$ & $38,49 \pm 14,15$ & \\
\hline BMI kg/m $\mathbf{m}^{2}$ & $29,09 \pm 6,023$ & $26,61 \pm 5,213$ \\
\hline FBG mmol/L & $6,03 \pm 1,830$ & $5,24 \pm 1,830$ \\
\hline Triglycerides $\mathbf{~ m m o l} / \mathbf{L}$ & $1,89 \pm 1,172$ & $1,76 \pm 1,201$ \\
\hline PASI SCORE & $25,27 \pm 7,88$ & \\
\hline
\end{tabular}

The prevalence and statistical data on MTHFR $677 \mathrm{C}>\mathrm{T}$ genotyping of the patients versus healthy psoriasis free controls are presented in Table 2.

The DNA analysis revealed $52.4 \%$ of cases with genotype CC, $34.9 \%$ of the cases with genotype CT and $12.7 \%$ of the cases with genotype TT, whereas the genotype distribution of controls was $42.2 \%$ with genotype CC, $47.1 \%$ with genotype CT and $10.7 \%$ with genotype TT respectively.

The statistical data:odd ratio, Pearson's ChiSquare, significance interval and exact Fisher probability (p) for the weight of TT genotype as a risk factor for psoriasis was calculated versus healthy controls and was respectively: $12.70 \%$ versus $10.80 \%$ in controls (OR $1.203, \mathrm{P}>0.05)$.

Table 2. MTHFR 677C>T genotypes and Statistical data on MTHFR $677 \mathrm{~T}$ prevalence and in psoriatic patients versus controls

\begin{tabular}{|c|c|c|c|c|c|}
\hline $\begin{array}{c}\text { MTHFR } \\
\text { 677C }>\text { T } \\
\text { genotypes }\end{array}$ & $\begin{array}{c}\text { Prevalence } \\
\text { in patients } \\
\%\end{array}$ & $\begin{array}{c}\text { Prevalence } \\
\text { in controls } \\
\%\end{array}$ & Odds Ratio & $\begin{array}{c}\text { 95\% } \\
\text { Confidence } \\
\text { Interval }\end{array}$ & $\begin{array}{c}\text { Fisher's } \\
\text { Exact } \\
\text { Test }\end{array}$ \\
\cline { 1 - 3 } TT & $12.70 \%$ & $10.7 \%$ & 1.203 & $0.456-3.175$ & $>0.05$ \\
\cline { 1 - 2 } CT & $34.9 \%$ & $47.1 \%$ & & & \\
\hline
\end{tabular}


There was a difference in the PASI scorebetween the patients depending on the genotype (table 3 ). It was higher in carriers of TT genotype of MTHFR polymorphism $677 \mathrm{C}>\mathrm{T} 28.18$ versus 24.69in non-carriers. However, because of the high value of standard deviation, it was not significant $(\mathrm{p}>0.05)$.

Table 3. PASI index in carriers of MTHFR $677 \mathrm{~T}$ as compared to non-carriers

\begin{tabular}{|c|c|c|}
\hline $\begin{array}{l}\text { MTHFR 677C }>\text { T } \\
\text { genotypes }\end{array}$ & $\begin{array}{c}\text { PASI } \\
\text { INDEX }\end{array}$ & $\begin{array}{c}\text { Significance } \\
(\mathbf{p}>\mathbf{0 . 0 5})\end{array}$ \\
\hline TT & $28.18 \pm 5.42$ & $\mathrm{p}=0.2412$ \\
\hline $\mathbf{C T}+\mathbf{C C}$ & $24.69 \pm 7.78$ & \\
\hline
\end{tabular}

\section{DISCUSSION}

The relationship between psoriasis and MTHFR $677 \mathrm{C}>\mathrm{T}$ polymorphism is still not well-understood. The prevalence of the MTHFR $677 \mathrm{C}>\mathrm{T}$ polymorphism diverges substantially among different populations. [19]The prevalence of polymorphism in our population is well established, it is roughly $10-12 \%$. Our data have provideda prevalence of $10.8 \%$ for the TT genotype in the population. The frequency of the MTHFR $677 \mathrm{~T}$ allele varies from $4 \%$ of the population in Finland, $6.4 \%$ in the Netherlands, $8 \%$ in Israel, $11.1 \%$ in Hungary, $11.8 \%$ in France and the Czech Republic and it was found as high as $19.8 \%$ in North China, and $32 \%$ in Mexico, etc.[20] Variability of its world distribution is related to the availability of vitamins like folic acid (B9), B12, absorption of vitamins, various minerals, essential fatty acids and amino acids that interact with folic acid.

The results on the association of carriage of $677 \mathrm{C}>\mathrm{T}$ MTHFR gene polymorphism with psoriasis vulgaris in different regions of the world are rather conflicting.

Our data haven't revealed any significant difference between carriage of $\mathrm{T}$ genotype among the patients with plaque psoriasis and healthy, non-psoriatic controls (OR 1.203, $\mathrm{p}>0.05$ ).

Wang et al. had presented the firstdata on the association of MTHFR $677 \mathrm{C}>\mathrm{T}$ gene polymorphism with psoriasis vulgaris for the Chinese population.[21]A significant association between MTHFR 677 TT genotype and psoriasis was found as well in the study of the psoriatic patients from the Turkish ethnic groups: CC (35.4\%), CT $(47.9 \%)$ and TT $(16.7 \%)$; whereas the distribution of in the control group was as follows CC $50.6 \%$, CT $45.5 \%$ and TT $3.9 \%$. Moreover, a significant difference between the severity of disease $(\mathrm{p}<0.05)$ with respect to the carriage of C677T polymorphism in the MTHFR gene was shown for the Turkish population.[22]These results were confirmed by the study of the Iranian group, postulating that MTHFR
$677 \mathrm{~T}$ allele frequencies in psoriatic patients were significantly higher than in the control group $(28.5 \%$ vs $18.5 \%$; $\mathrm{p}=0.018)$.[19]

Indeed, in the European population, the investigation of the Czech Republic presents a lower carriage of the MTHFR TT allele (10.5\%) in patients with plaque psoriasis as compared to controls $(11.8 \%)$. [23] The results of Weger (Austria) showed that the prevalence of the homozygous TT genotype was not significantly higher in the patients than in controls $(15.2 \%$ vs $11.7 \%, \mathrm{P}=0.24)$. [24] These results established for Caucasians are in coherence with our finding for the Bulgarian population that the difference between the prevalence of the homozygous TT in psoriatic patients and the control group is not significant. It looks logical, as these investigated groups belong to the same Caucasian race. The aforementioned results on a higher prevalence of TT allele in psoriatic patients could be related to the geographic specificity of the investigated groups, belonging more to the Asian and Middle East population. Recently a newly published investigation in the same region again confirmed the link between carriage of the T-allele of MTHFR $677 \mathrm{~T}$ and psoriasis in Saudi patients was stating that carriage of.[25]

The plausible difference in ethnicity was suggested to explain these contradictory findings on MTHFR $677 \mathrm{C}>\mathrm{T}$ polymorphism.

\section{CONCLUSION}

Our results show that carriage of the TT genotype of MTHFR polymorphism $677 \mathrm{C}>\mathrm{T}$ was not significantly associated with psoriasis vulgaris in the Bulgarian population when compared to healthy controls.

The severity of psoriasis was higher (a higher PASI) in the patients, carriers of TT genotype of MTHFR polymorphism $677 \mathrm{C}>\mathrm{T}$ than in non-carriers, but the data was not significant. The drawback of our study was the size of the sample. To get more reliable data, the investigation of more patients is needed.
Abbreviations:
MTHFR - Methylenetetrahydrofolate reductase
PASI - Psoriasis Area and Severity Index
PCR- Polymerase chain reaction
RFLP - Restriction Fragment Length Polymorphism
SAM- S-Adenosyl-Methionine
FBG- Fasting blood glucose
TAG - triacylglycerol
BMI - Body Mass Index

\section{Acknowledgements:}

This work was supported by the Medical University of Pleven grant No. 19/2019.Project No. 19/2019 


\section{REFERENCES:}

1. Balta I, Balta S, Demirkol S, Celik T, Ekiz O, Cakar M, et al. Aortic arterial stiffness is a moderate predictor of cardiovascular disease in patients with psoriasis vulgaris. Angiology. 2014 Jan;65(1):74-8. [PubMed] [Crossref]

2. Izmirli M, Sen BB, Rifaioglu E, Gogebakan B, Aldemir O, Sen T, et al. Methylenetetrahydrofolate reductase (MTHFR) C677T polymorphism in psoriasis in southern Turkey. An Bras Dermatol. 2016 Sep-Oct;91(5):611613. [PubMed] [Crossref]

3. Goyette P, Pai A, Milos R, Frosst $\mathrm{P}$, Tran P, Chen Z, et al. Gene structure of human and mouse methylenetetrahydrofolate reductase (MTHFR). Mamm Genome. 1998 Aug;9(8):652-6. [PubMed] [Crossref]

4. Sibani S, Leclerc D, Weisberg IS, O'Ferrall E, Watkins D, Artigas C, et al. Characterization of mutations in severe methylenetetrahydrofolate reductase deficiency reveals an FAD-responsive mutation. Hum Mutat. 2003 May;21(5):509-20. [PubMed] [Crossref]

5. Ueland PM, Hustad S, Schneede J, Refsum H, Vollset SE. Biological and clinical implications of the MTHFR C677T polymorphism. Trends Pharmacol Sci. 2001 Apr;22(4):195-201. [ [PubMed] [Crossref]

6. Weisberg I, Tran P, Christensen B, Sibani S, Rozen R. A second genetic polymorphism in methylenetetrahydrofolate reductase (MTHFR) associated with decreased enzyme activity. Mol Genet Metab. 1998 Jul;64(3):169-72.

[PubMed] [Crossref]

7. Dos Santos Nunes MK, Silva AS, de Queiroga Evangelista IW, Filho JM, Gomes CNAP, do Nascimento RAF, et al. Hypermethylation in the promoter of the MTHFR gene is associated with diabetic complications and biochemical indicators. Diabetol Metab Syndr. 2017 Oct 18;9:84. [PubMed] [Crossref]

8. Weger W, Hofer A, Stanger O, Wolf P, El-Shabrawi Y, Renner W, et al. The methylenetetrahydrofolate reductase $677 \mathrm{C}>\mathrm{T}$ gene polymorphism is not associated with chronic plaque psoriasis. Exp Dermatol. 2008 Sep;17(9):748-51. [PubMed] [Crossref]

9. Sibani S, Christensen B, O'Ferrall E, Saadi I, Hiou-Tim F, Rosenblatt DS, et al. Characterization of six novel mutations in the methylenetetrahydrofolate reductase (MTHFR) gene in patients with homocystinuria. Hum Mutat. 2000; 15(3):280-7. [PubMed] [Crossref]

10. Liew SC, Gupta ED. Methylenetetrahydrofolate reductase (MTHFR) C677T polymorphism: epidemiology, metabolism and the associated diseases. Eur J Med Genet. 2015 Jan;58(1):1-10. [PubMed] [Crossref]

11. Kang SS, Zhou J, Wong PW, Kowalisyn J, Strokosch G. Intermediate homocysteinemia: a thermolabile variant of methylenetetrahydrofolate reductase. Am J Hum Genet. 1988 Oct;43(4):414-21. [PubMed]

12. Karimian M, Colagar AH. Association of C677T transition of the human methylenetetrahydrofolate reductase (MTHFR) gene with male infertility. Reprod Fertil Dev. 2016 Apr;28(6):785-94. [PubMed] [Crossref]

13. Lu Q, Jiang K, Li Q, Ji YJ, Chen WL, Xue XH. Polymorphisms in the MTHFR gene are associated with breast cancer risk and prognosis in a Chinese population. Tumour Biol. 2015 May;36(5):3757-62. [PubMed] [Crossref]

14. Nygård $\mathrm{O}$, Nordrehaug JE, Refsum H, Ueland PM, Farstad M, Vollset SE. Plasma homocysteine levels and mortality in patients with coronary artery disease. $N$ Engl J Med. 1997 Jul 24;337(4):230-6. [PubMed] [Crossref]

15. Tobin AM, Hughes R, Hand EB, Leong T, Graham IM, Kirby B. Homocysteine status and cardiovascular risk factors in patients with psoriasis: a case-control study. Clin Exp Dermatol. 2011 Jan;36(1):19-23. [PubMed] [Crossref]

16. Liew SC, Das-Gupta E, Wong SF, Lee N, Safdar N, Jamil A. Association of methylentetraydrofolate reductase (MTHFR) $677 \mathrm{C}>\mathrm{T}$ gene poly- morphism and homocysteine levels in psoriasis vulgaris patients from Malaysia: a case-control study. Nutr J. 2012 Jan 5;11:1. [PubMed] [Crossref]

17. Asefi M, Vaisi-Raygani A, Khodarahmi R, Nemati H, Rahimi Z, Vaisi-Raygani H, et al. Methylentetrahydrofolatereductase (rs1801133) polymorphism and psoriasis: contribution to oxidative stress, lipid peroxidation and correlation with vascular adhesion protein 1, preliminary report. J Eur Acad Dermatol Venereol. 2014 Sep;28(9):1192-8. [PubMed] [Crossref]

18. Sell SM, Lugemwa PR. Development of a highly accurate, rapid PCR-RFLP genotyping assay for the methylenetetrahydrofolate reductase gene. Genet Test. 1999; 3(3):287-9. [PubMed] [Crossref]

19. Pepe G, Camacho Vanegas O, Giusti B, Brunelli T, Marcucci R, Attanasio M, et al. Heterogeneity in world distribution of the thermolabile C677T mutation in 5,10methylenetetrahydrofolate reductase. Am J Hum Genet. 1998 Sep;63(3):917-20. [PubMed] [Crossref]

20. Schneider JA, Rees DC, Liu YT, Clegg JB. Worldwide distribution of a common methylenetetrahydrofolate reductase mutation. Am J Hum Genet. 1998 May;62(5):1258-60. [PubMed] [Crossref]

21. Baiqiu W, Songbin F, Guiyin $\mathrm{Z}, \mathrm{Pu}$ L. Study of the relationship between psoriasis and the polymorphic site C677T of methylenetetrahydrofolate reductase. Chin Med Sci J. 2000 Jun;15(2):119-20. [PubMed]

22. Karabacak E, Aydin E, Ozcan O, Dogan B, Gultepe M, Cosar A, et al. Methylenetetrahydrofolate reductase (MTHFR) $677 \mathrm{C}>\mathrm{T}$ gene polymorphism as a possible factor for reducing clinical severity of psoriasis. Int J Clin Exp Med. 2014 Mar 15;7(3):697-702. [PubMed]

23. Vasku V, Bienertova-Vasku J, Necas M, Vasku A. MTHFR (methylenetetrahydrofolate reductase) C677T polymorphism and psoriasis. Clin Exp Med. 2009 Dec;9(4): 32731. [PubMed] [Crossref] 
24. Weger W, Hofer A, Stanger O, Wolf P, El-Shabrawi Y, Renner W, et al. The methylenetetrahydrofolate reductase $677 \mathrm{C}>\mathrm{T}$ gene polymorphism is not associated with chronic plaque psoriasis. Exp Dermatol. 2008 Sep;17(9):748-51. [Crossref]
25. Huraib GB, Harthi FA, Arfin M, Khlaiwi AA, Rizvi S, Al-Asmari A. Methylenetetrahydrofolate Reductase C677T Gene Polymorphism as Risk Factor for Psoriasis in Saudis. Biomark Insights. 2019 Feb 24; 14 : 1177271919830973 . [PubMed] [Crossref]

Please cite this article as: Dimitrov B, Gospodinov D, Gincheva V, Komsa-Penkova R. Prevalence of MTHFR gene 677C $>$ T polymorphism in the patients with Psoriasis Vulgaris. J of IMAB. 2021 Apr-Jun;27(2):3707-3711.

DOI: https://doi.org/10.5272/jimab.2021272.3707

Received: 05/06/2020; Published online: 23/04/2021

Address for correspondence:

Borislav Tsvetanov Dimitrov,

Assistant Professor at Department of Chemistry \& Biochemistry, Medical University - Pleven,

1, St. Kliment Ohridski Str., 5800 Pleven, Bulgaria.

E-mail: bobi.tsvetanov@gmail.com, 